\title{
INTEGRATED WATERSHED MANAGEMENT AND FLOODPLAIN PROTECTION ON THE CARSON RIVER IN THE WESTERN USA
}

\author{
JOHN COBOURN \& STEVEN R. LEWIS \\ University of Nevada Cooperative Extension, USA
}

\begin{abstract}
The Carson River in western Nevada, USA, flows approximately 200 miles (320 km) from its headwaters in the central Sierra Nevada range to its terminal wetlands in Nevada's Great Basin Desert. The nearly 4,000 square mile $\left(10,400 \mathrm{~km}^{2}\right)$ watershed is home to about 156,000 people. A year after a major flood event in 1997, local citizens and agency staff came together to form an Integrated Watershed Management group called the Carson River Coalition (CRC). Rather than focusing solely on flood problems, the group pledged to address all problems of flooding, water quantity, water quality and wildlife habitat in an integrated fashion through improved communication and collaboration. In 2003, the group decided to determine its 'main message', the single most important message the public needs to understand about the watershed. Over 50 group members participated, and the message was defined as, 'Protect the floodplain from future development'. Since 2003, CRC members, working with the staff of a regional water management agency, have written the Regional Floodplain Management Plan of 2008 (RFMP). It explains the functions, values and ecosystem services of natural floodplains. Much of the floodplain near the channel is used for privately owned farms and pasturelands. This land use is compatible with the RFMP's goals. However, the population of the watershed is projected to grow, and the floodplain is beginning to be developed for urban infrastructure. To help focus public attention on the value of protecting floodplains, CRC members engaged a County geographic information systems specialist to map the location of all properties in the riverine floodplain protected by conservation easements or public ownership. This map was introduced in a University of Nevada Cooperative Extension Special Publication in 2015. It serves as a call to action and baseline inventory for measuring progress towards the community goal of protecting the Carson River's natural floodplains.
\end{abstract}

Keywords: Carson River, floodplain management, GIS, integrated watershed management, non-structural, protected floodplain, riverine, storm events, watershed

\section{INTRODUCTION}

Most of the headwaters of the Carson River arise from the snowpack of the central Sierra Nevada range in California. The high drainages spring from peaks of 10,000 to 11,000 feet $(3,000-3,300 \mathrm{~m})$ in elevation, and they flow east and north into the Great Basin Desert of Nevada, the driest state in the USA. The river itself is about 200 miles $(320 \mathrm{~km})$ long, and the lower reaches lie in the rain shadow of the Sierra Nevada. The watershed is home to about 156,000 people, but approximately $90 \%$ of surface and groundwater use is for irrigated agriculture $[1,2]$.

European-American settlement began at the time of the California Gold Rush in 1849 and accelerated with the boom in gold and silver mining in the famous Comstock Lode in Virginia City, Nevada, in the 1860 s and 1870 s. The boom ended by 1900 , and for the first half of the 20th century, the economy of the watershed was based mostly on ranching and alfalfa farming. The population surged again after the end of the Second World War, when the state Capital of Carson City and the nearby towns of Minden, Gardnerville, Dayton and Fallon began to grow (Fig. 1).

Because many of the forests in the watershed were logged during the mining boom, and because thousands of logs were rafted down the Carson River for transport to the mines, the 


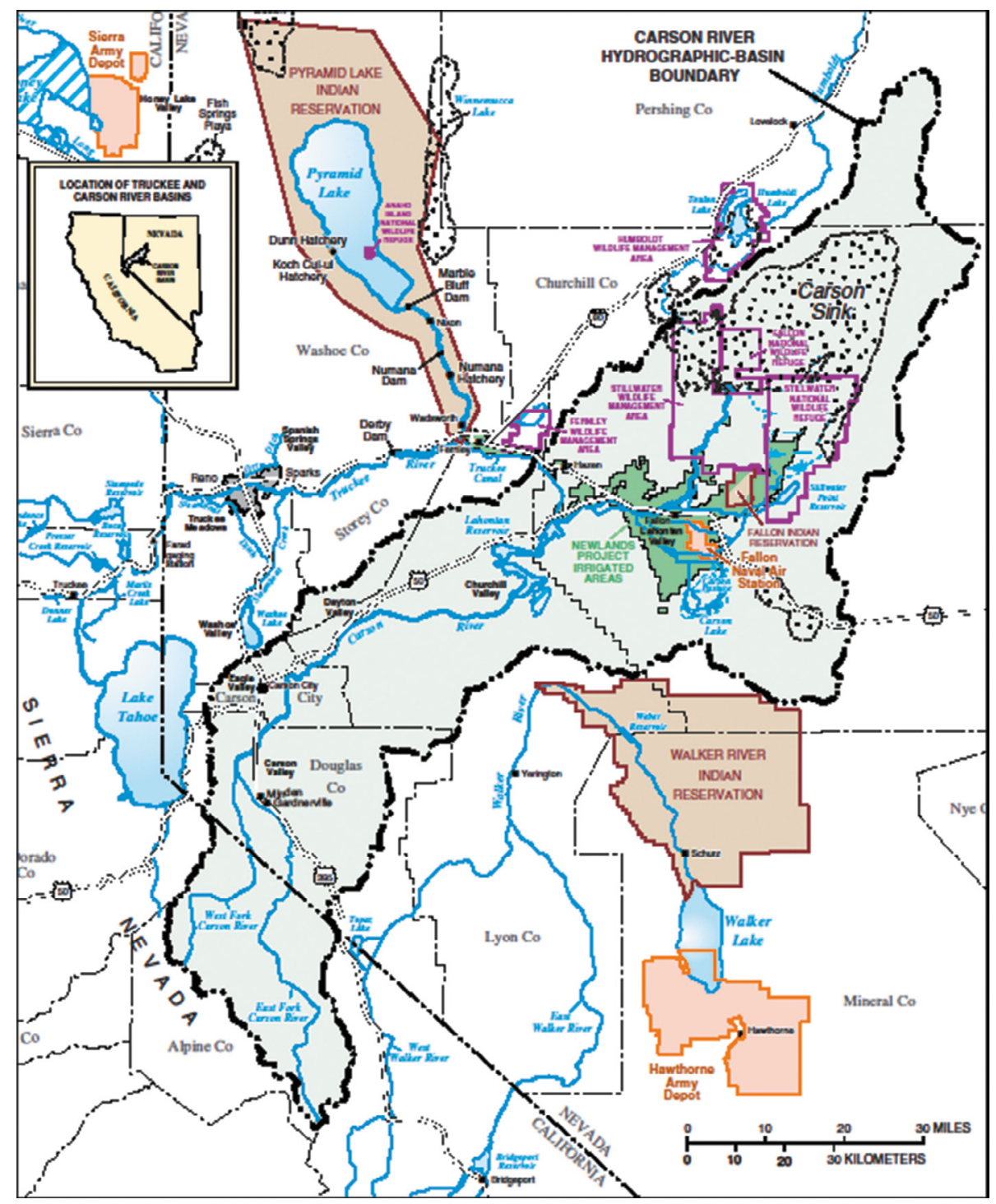

Figure 1: USGS hydrologic features map of the Carson River watershed and surroundings [2].

river channel became incised in valley floors, and water quality suffered. By the 1990s, local communities teamed up with state and federal agencies to stabilize raw, eroding banks and attempt to meet the standards of the Clean Water Act [1].

Between 30 December 1996 and 3 January 1997, a large, warm atmospheric river storm unleashed up to 17 inches of rain in the headwaters areas of the watershed. Known as the New Year's Flood of 1997, this 'rain-on-snow' storm event produced severe flooding on many large watersheds originating in the Sierra Nevada, including the Carson River and the Truckee River just to the north. These floods crippled downstream communities for days. Hundreds of millions of dollars of flood damages occurred in the city of Reno, Nevada, on 
the Truckee River, just 30 miles north of Carson City. In the Carson Valley, near Minden and Gardnerville, agricultural fields flooded and created a shallow lake over 10 miles long and 3-4 miles wide in places [2, 3]. See Fig. 1.

While many Nevada residents were shocked by this severe flood in the western side of the Great Basin Desert, this flood was not unique. Over the past 160 years, large river floods have occurred on western Nevada rivers about every 10-20 years. Floods in 1950 and 1955 were comparable in size to the New Year's flood of 1997 [2].

In the year following the 1997 flood, citizens, agency staff and University of Nevada Cooperative Extension educators came together to organize the first major watershed conference on the Carson River. Many believed that the Carson River was so important to the community that it deserved to be cared for and managed using the practices of integrated watershed management (IWM). Two weeks after the watershed conference, which was attended by 250 participants, the organizers held a follow-up workshop where they asked participants to consider the pros and cons of establishing a watershed management group based on the principles of IWM. At the end of the workshop, participants overwhelmingly voted to support such a process, and the Carson River Coalition (CRC) was born. A regional water management agency known as the Carson Water Subconservancy District (CWSD) was selected to house and support this new citizen and inter-agency watershed group.

\section{DEFINING IWM}

The concept of watershed management has been developed by scientists, government officials and educators over the past century. In the early 1990s, the Universities Council on Water Resources devoted the autumn 1993 and the summer 1995 issues of its journal, Water Resources Update, to articles on the concept of IWM. Cobourn mined these articles for key ideas and created a list of the 'defining characteristics of IWM' [4]. These were used to evaluate the degree to which the Truckee River was planning and managing the watershed according to IWM [4]. Some of the most important characteristics are the following:

1. It is holistic. It looks at many issues and problems and their interrelationships, not single issues or 'projects' [5, 6].

2. It addresses issues of water quality, water quantity, habitat and floodplain management in an integrated fashion [5].

3. It is interdisciplinary. It addresses the whole ecosystem, including the human dimension. Property owners, developers, engineers, resource managers, agricultural producers, attorneys, etc., need to join the team [7, 8].

4. It aims at long-term sustainability, considering current and future problems, solutions and consequences $[9,10]$.

5. Since watersheds cross jurisdictions, collaboration is needed between all levels of government. This requires communicating, joining forces and sharing 'territory' $[7,11,12]$.

More recent definitions echo many of these characteristics. In Canada, the group Conservation Ontario stresses the interaction of human and natural processes in its definition: 'Integrated Watershed Management (IWM) is the process of managing human activities and natural resources on a watershed basis. This approach allows us to protect important water resources, while at the same time addressing critical issues such as the current and future impacts of rapid growth and climate change' [13]. 
University of Arizona professor J.E. de Steiguer [14] emphasizes the importance of stakeholder input to the success of this kind of planning. 'Integrated Watershed Management (IWM) has emerged worldwide as the preferred model for watershed planning. IWM uses the watershed as the basic geographic planning unit while integrating social, economic, ecological and policy concerns with science to develop the best plan. Stakeholder input is key to successful IWM' [14].

\section{GETTING STARTED WITH IWM PLANNING}

The Carson River watershed conference organizers were aware of the principles of IWM in 1998 and wanted to give this ambitious concept a try. One of the organizers was an engineer who was on contract to manage the CWSD. This regional body had been formed by the Nevada Legislature in the 1950s to plan for possible storage reservoirs on the upper Carson River (which were never built).

Today, the CWSD is a six-county, bistate regional watershed agency. Its 14 member board of directors consists of elected representatives from each county in the watershed as well as several representatives from the agricultural community [15]. The fact that this board is composed of elected officials from several local governments and by agricultural stakeholders is crucial to the success of this agency and its watershed management efforts.

CWSD's mission is to work within existing governmental frameworks to promote cooperative action for the watershed that crosses both agency and political boundaries. CWSD acts as lead agency for integrated watershed planning and funds the CRC. The CRC is a watershedwide stakeholder group that serves as the steering committee for the integrated watershed planning process. CWSD strives to involve all counties and communities within the watershed in the effort to meet future water needs, enhance the health of the river system, protect the floodplains and provide outreach and information to the community [15].

In 1998, CWSD hired a full-time general manager and soon after obtained funding from the Nevada Division of Environmental Protection to hire a watershed coordinator for the CRC. Attendance at monthly CRC meetings was regularly 30 or more people, and the group soon hammered out a list of 'Watershed Management Guiding Principles.' These principles became the basis for the Carson River Watershed Adaptive Stewardship Plan, prepared by CWSD in 2006 [15]. These principles are shown in Table 1.

In 2003, University of Nevada Cooperative Extension faculty asked the members of the $\mathrm{CRC}$ to conduct a group process to determine the single most important message to convey to the general public about the watershed. Over 50 members participated, and they reached consensus that this 'main message' was

Protect the floodplain from future development. Once the floodplain and especially the river's meander belt corridor are impacted by development, the river loses the ability to reestablish its natural functions. Agricultural fields near the channel are critical for floodwater attenuation, ground water recharge, non-point source pollution buffering and providing habitat for wildlife [16].

\section{FLOODPLAIN MANAGEMENT IN THE CONTEXT OF IWM}

As noted above, there was a major river flood in 1997, a little over a year before the Carson River Conference was held in 1998 and the CRC was formally established. The conference organizers did not see the conference and the CRC simply as responses to the flooding. Note 
Table 1: Carson River watershed management guiding principles [15].

1) Manage the water's resources for economic sustainability, quality of life and protection of private and public property rights.

2) Acknowledge and respect the watershed's natural processes in land use decisions.

3) Maintain or improve the quality of the water to support a variety of beneficial uses.

4) Protect the headwaters region as the system's principal water source.

5) Recognize and respect the interests of all stakeholders upstream and downstream by fostering collaborative and mutually respectful relationships.

6) Maintain the riverine and alluvial fan floodplains of the Carson River watershed to accommodate flood events.

7) Protect and manage uplands, mountain ranges, wetlands and riparian areas to enhance the quality of surface flow, groundwater recharge and wildlife habitat.

8) Promote conservation of water from all sectors of the community's water users for the benefit of municipal, industrial, agricultural domestic, recreational and natural resources.

9) Encourage management of growth that considers water quality and quantity, open space preservation and maintenance of agriculture in floodplains.

10) Protect and support opportunities for public recreational access to natural areas throughout the watershed - including the river corridor - where appropriate.

11) Promote understanding and awareness of watershed resources and issues through cooperative education efforts throughout the watershed.

that the guiding principles in Table 1 call for protection of the riverine floodplain not just to attenuate floodwaters but also to maintain the river's 'natural processes,' recharging groundwater and maintaining surface water quality and wildlife habitat. CRC members certainly agreed that the magnitude of large river floods such as the 1997 New Year's Flood demanded preparedness and floodplain management [17]. But they insisted that flood control structures were not the best answers to the problem.

One of the keynote speakers at the 1998 conference was Dr. Jeff Mount, at that time, the chair of the Geology Department at University of California at Davis. Dr. Mount, author of California Rivers and Streams [18], spoke about what he referred to as the vicious cycle of 'serial engineering' that often occurs on riverine floodplains. Echoing many of the conclusions in the US Army Corps of Engineer's 1994 'Galloway Report,' [19], Dr. Mount pointed out that once structures such as homes or businesses are built in a floodplain and are flooded, property owners call for flood control structures to protect them. After levees are built, people feel safe, and more structures are built there. Then a larger flood occurs, and this cycle of flooding and levee construction continues until the river is put into an extremely expensive concrete channel, such as the channel of the Los Angeles River. When that happens, the fish, wildlife and water quality values are lost. Furthermore, preventing the storage of flood waters on floodplains increases peak flows during both rain-on-snow and spring snowmelt flood events. These increased flows increase flood hazards for all downstream communities.

After the CRC agreed on its 'main message [16]', its members and coordinator began work on the Carson River Watershed Regional Floodplain Management Plan (RFMP) of 2008 [20]. This plan was grounded on guiding principles 2, 6 and 9 (from Table 1) and on the 'main message.' It also developed an important economic argument that spending money now on 
floodplain protection will save much larger sums of money that would be spent on damages in the future if the floodplain turns into subdivisions and industrial parks. One key element in this argument was the fact that flood damages in the built-up floodplains of the Truckee River in Reno and Sparks, about 30 miles to the north, were 30 times more expensive than flood damages in the relatively undeveloped floodplains of the Carson River watershed.

The RFMP analyses the hazards of riverine flooding and presents a long list of 'suggested actions' for 'flood risk reduction and floodplain protection' [20]. The central thrust for these actions is: 'Protect Natural Floodplain Functions and Values' [20]. This goal is described in terms of what is called the 'Living River Approach' [20]. The goal of this approach is to maintain a river environment which:

- provides un-impeded flow conditions and connection of the river to its floodplain;

- minimizes disruption and alteration of river and riparian habitat;

- conveys variable flows and restores habitat in floodplain;

- balances sediment input with sediment transport;

- provides fish and wildlife habitat;

- enhances water quality and supply;

- maintains aesthetic and recreational qualities [20].

Though the Carson River's channel is incised in many places, and many riparian areas are denuded because of steep eroding banks, at least the floodplain is still used mainly for agriculture. The RFMP recognizes that if riverfront homes and urban infrastructure can be kept to a minimum, the cycle of 'serial engineering' can be prevented. If the above characteristics of a living river can be restored, they will provide flood water attenuation and other ecosystem services for the community in the future. Non-structural floodplain management methods are recommended over structural flood control measures. For example, the suggested actions of the RFMP urge river communities to protect the natural functions and benefits of floodplain lands, to consider flood hazards when prioritizing acquisition targets for open space programs and to 'retain lands that provide floodplain storage and maintain or restore connection of the river with its floodplain through land acquisition, conservation easements, local open space programs, transfer of development rights (TDR) ... and other protection methods' [20].

\section{THE CHALLENGE OF PROTECTING FLOODPLAIN LANDS}

Most of the floodplain land along the channel of the Carson River is private property, owned by cattle ranchers and alfalfa farmers. However, the watershed and particularly the Carson and Dayton Valleys are near enough to Reno and Carson City to experience growth pressure. As ranchers near retirement age, they sometimes find that their children do not want to take on the hard work of running the ranch. During times of economic growth, land developers often look for opportunities to divide ranches into small-acreage ranches ('ranchettes'). Many people are still drawn to the lure of a riverfront home.

County planners in Douglas County have zoned much of the riverine floodplain for a maximum of one house per 19 acres ( 7 ha). They have also created a Transfer of Development Rights (TDR) programme which allows property owners to sell development rights of floodplain properties to developers in 'receiving areas' which are not in flood hazard zones [21]. In addition, NGOs such as The Nature Conservancy have raised funds to purchase and retire the development rights on some ranches, placing a permanent conservation easement on the deed. 
Members of the CRC reaffirmed that protection of floodplain lands from development was still their 'main message' in 2012. They wondered at that time if the message was actually getting out to the public and, more importantly, if floodplain lands were actually being protected. CRC members felt that an inventory of protected floodplain lands would be helpful to act as a 'report card' for showing progress towards this community goal. In 2013, two Cooperative Extension faculty members formed a small group to research this question and to develop a map and inventory.

\section{CREATING A FLOODPLAIN PROTECTION INVENTORY}

The group who worked on the inventory included the floodplain managers and engineers from the three counties in the watershed with the most floodplain lands at risk from development. It also included local open space managers, consultants and staff of local NGOs working on conservation easement opportunities, plus the two cooperative extension faculty. Douglas County contributed the time and support of its geographic information systems (GIS) supervisor.

The group decided to inventory riverine floodplains only. Alluvial fan flood zones would be the subject of a future study. They chose to define the floodplain as the Federal Emergency Management Agency's (FEMA) 'one-percent-chance' flood zone, which has a 1-in100 chance of flooding in any given year, combined with the boundaries of the area actually flooded in January 1997, as mapped in the Nevada Bureau of Mines and Geology's 'Flood Extent Map' [2]. These two areas are similar in size and shape. The FEMA one-percentchance flood zone is also known as the 100-year flood zone or Zone A, and it defines zones of risk called Special Flood Hazard Areas. Since the FEMA flood zone is to some degree hypothetical, we included additional areas that flooded in the large (80+-year) 1997 flood as a way of ensuring a conservative picture of lands known to be at relatively high risk of flooding. This combined floodplain is shown in blue on our maps.

For the purpose of this inventory, 'protected floodplain' refers to land that is either publically owned or privately owned and not likely to be developed. Briefly, 'protected' parcels include the following:

- Open space and parks owned by federal, state, county, city or general improvement district agencies.

- Privately owned land with a conservation easement and/or development restrictions (including those small parcels in Douglas County's Transfer of Development Rights Program).

- Privately owned open space - by homeowner associations (common areas) [22].

Group members were asked to forward legal descriptions of protected floodplain lands to the GIS mapmaker. The results of this inventory are illustrated in e-maps (Figs 2 and 3), with the unprotected floodplain shown in blue and with parcels of protected land shown as green polygons.

We tallied the total number of acres of floodplain lands and protected parcels in each county in Table 2. The total area of the combined riverine floodplains amounts to 39,879 acres (16,138 ha) within Douglas County, Carson City and Lyon County. Within this floodplain area, $31 \%$ have been identified as protected and $69 \%$ as unprotected. Specific acreages and percentages for each county are shown in Table 2 [22]. 


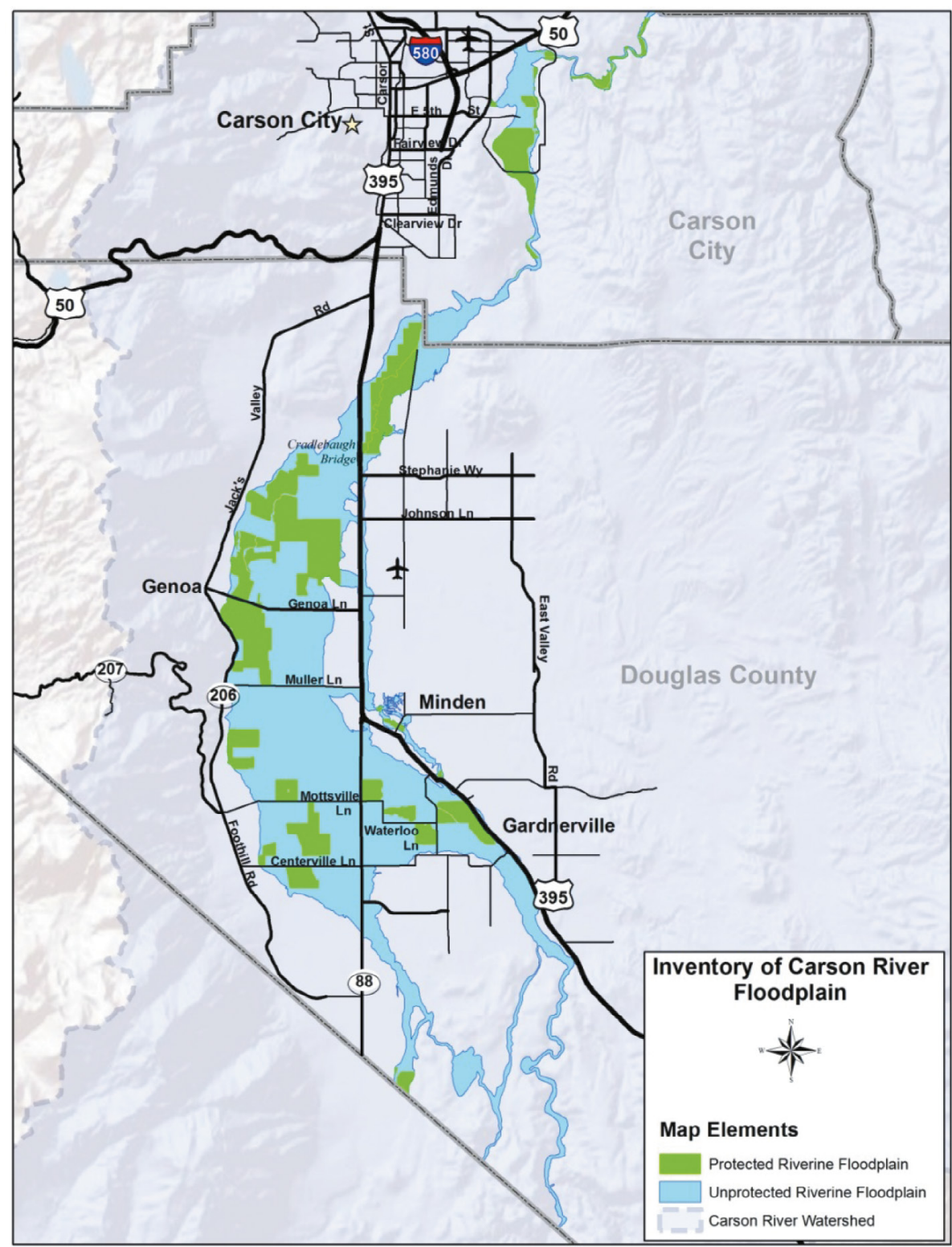

Figure 2: Map of protected and unprotected riverine floodplain lands within Douglas County and Carson City in the Carson River watershed as of 2015 [22].

\section{USING THE INVENTORY FOR PUBLIC OUTREACH EDUCATION}

The CRC members who called for this inventory wished to get the information out to the residents of the watershed, so the data and maps were compiled into a readable 'Special Publication' and published by Cooperative Extension. The 6-page publication explains the functions and values of undeveloped floodplains, explores why and how they could be protected and presents the maps and data in clear terms. It also poses the choice that the people and local 


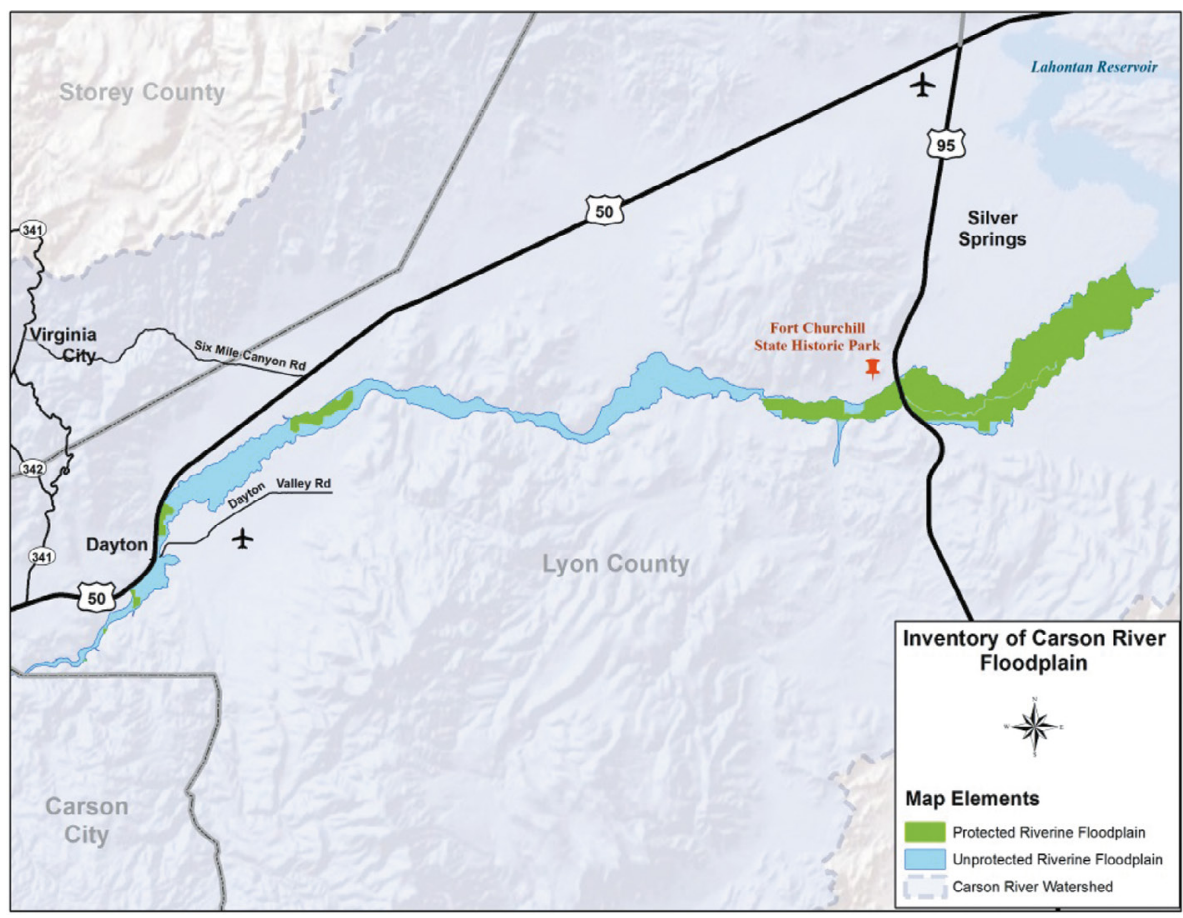

Figure 3: Map of protected and unprotected riverine floodplain lands within Lyon County in the Carson River watershed as of 2015 [22].

Table 2: Acres and percent of protected and unprotected riverine floodplain in Douglas County, Carson City and Lyon County within the Carson River Watershed as of 2015 [22].

\begin{tabular}{llclcl}
\hline County & $\begin{array}{l}\text { Protected } \\
\text { floodplain } \\
\text { acreage (ha) }\end{array}$ & $\begin{array}{l}\text { \% Protected } \\
\text { floodplain }\end{array}$ & $\begin{array}{l}\text { Unprotected } \\
\text { floodplain acre- } \\
\text { age (ha) }\end{array}$ & $\begin{array}{l}\% \\
\text { Unprotected } \\
\text { floodplain }\end{array}$ & $\begin{array}{l}\text { Total riverine } \\
\text { floodplain } \\
\text { acreage (ha) }\end{array}$ \\
\hline Douglas & $6,009 / 2,431$ & 23 & $20,182 / 8,113$ & 77 & $26,191 / 10,544$ \\
Carson & $903 / 365$ & 36 & $1,588 / 638$ & 64 & $2,491 / 1,003$ \\
Lyon & $5,403 / 2,186$ & 48 & $5,794 / 2,329$ & 52 & $11,197 / 4,515$ \\
Total & $12,315 / 4,983$ & 31 & $27,564 / 11,081$ & 69 & $39,879 / 16,064$ \\
\hline
\end{tabular}

governments in the watershed need to make. It is a choice between protecting undeveloped floodplains and letting them be gradually developed for subdivisions, business parks, resorts and small ranches. The latter choice could lead to the eventual construction of an expensive concrete-lined flood channel to replace the river and its aquatic and riparian ecosystems. This could increase flood hazards to downstream communities, including Fallon, Nevada, below the Lahontan Reservoir.

In order to achieve the goal of protecting riverine floodplains, millions of dollars of funding is needed to compensate private landowners for the cost of retiring development rights using 
conservation easements or other means. Many local ranchers would consider such solutions if the money was available. CRC members seek to spread the word about the benefits of protecting floodplain functions to the general public. NGOs like The Nature Conservancy and local consultants, Legacy Land and Water, can assist ranchers with the process, which includes seeking funding, getting appraisals and writing contracts, and they have succeeded in protecting a few ranches so far.

It is up to the watershed residents to decide which future they want for the river. Protecting floodplains usually takes private donations or public funds in the form of a bond initiative, a sales tax increase or other mechanism in order to compensate private property owners for the economic value of their development rights. Approving such a measure takes considerable public support and political will. The CRC works constantly to build the watershed literacy of local residents, so they can see and appreciate the value of IWM. Floodplain management is an example of the kind of issue that affects and is affected by all other natural resources and human activities in a watershed.

The Floodplain Protection Inventory provides a benchmark or baseline of the location and percentage of protected floodplain land within Douglas County, Carson City and Lyon County, Nevada. The same analysis can be conducted again in the future to track progress toward protecting riverine floodplains. In the meantime, these data can be used to help answer questions such as: Are all floodplain lands equally important to protect, or should floodway and other high-risk parcels close to the channel be considered higher priority? So in addition to educating the public, the inventory can be used to refine the broad objectives outlined in the Carson River watershed RFMP.

\section{REFERENCES}

[1] Azad, G., Cobourn, J., Kaffer, D., Lewis, S.R., Riedl, M.K. \& Skelly, J.A., The Carson River Watershed Map: Our Lifeline in the Desert, University of Nevada Cooperative Extension, Special Publication-03-02, available at www.unce.unr.edu/publications/ files/ag/2003/sp0302.pdf, 2003 (accessed 7 March 2017).

[2] Trionfante, J.V. \& Peltz, L.A., Hydrologic Features of the Truckee and Carson River Basins and Adjacent Areas, Western Nevada and Eastern California. USGS Report 93-368, available at https://pubs.usgs.gov/of/1993/0368/report.pdf, 1994 (accessed 7 March 2017).

[3] Rigby, J.G., Crompton, E., Berry, K., Yildirim, U., Hickman, S.F. \& Davis, D.A., The 1997 New Year's Floods in Western Nevada, Nevada Bureau of Mines and Geology, Special Publication 23, Reno, NV, 1998.

[4] Cobourn, J., Integrated Watershed Management on the Truckee River in Nevada. Journal of American Water Resources Association, 35(3), pp. 623-632, 1999. DOI: 10.1111/j.1752-1688.1999.tb03618.x.

[5] Nelson, D., Water education in Integrated Watershed Management. Water Resources Update, 93, pp. 34-37, available at http://ucowr.org/files/Achieved_Journal_Issues/ V93Water\%20Education\%20Integrated\%20Watershed\%20Management.pdf, 1993 (accessed 20 Sept 2017).

[6] Ballweber, J.A., Prospects for comprehensive, Integrated Watershed Management under existing law. Water Resources Update, 100, pp. 19-23, available at http:// opensiuc.lib.siu.edu/cgi/viewcontent.cgi?article=1353\&context=jcwre, 1995 (accessed 9 September 2017). 
[7] Wayland III, R.H., Comprehensive watershed management: A view from EPA. Water Resources Update, 93, pp. 23-26, 1993.

[8] Burt, J.P., New water resource challenges. Water Resources Update, 93, pp. 27-28, 1993.

[9] Cairns Jr., J., The economic basis for a partnership between human society and natural ecosystems. Water Resources Update, 93, pp. 18-22, available at http://ucowr.org/files/ Achieved_Journal_Issues/V93The_Economic_Basis_for_a_Partnership(1).pdf, 1993 (accessed 20 September 2017).

[10] Heaney, J.P., New directions in water resources planning and management. Water Resources Update, 93, pp. 3-8, available at http://opensiuc.lib.siu.edu/cgi/viewcontent. cgi?article=1412\&context=jcwre, 1993 (accessed 20 September 2017).

[11] Funk, W.H., A water problem that continues to be rediscovered: nonpoint source pollution. Water Resources Update, 93, pp. 9-12, available at http://opensiuc.lib.siu.edu/cgi/ viewcontent.cgi? article=1413\&context=jcwre, 1993 (accessed 20 September 2017).

[12] Margerum, R.D., Integrated Watershed Management: Comparing selected experiences in the U.S. and Australia. Water Resources Update, 100, pp. 36-47, available at http://opensiuc.lib.siu.edu/cgi/viewcontent.cgi?article=1356\&context=jcwre available at: http://opensiuc.lib.siu.edu/cgi/viewcontent.cgi? article=1356\&context=jcwre, 1995 (accessed 20 September 2017).

[13] Conservation Ontario, Integrated Watershed Management, available at conservationontario.ca/what-we-do/what-is-watershed-management/integrated-watershedmanagement (accessed 7 March 2017).

[14] de Steiguer, J.E., Duberstein, J. \& Lopes, V., The analytic hierarchy process as a means for Integrated Watershed Management. Presented at First Interagency Conference on Research in the Watersheds, Benson, AZ, 2003.

[15] Carson Water Subconservancy District (CWSD), Carson River Watershed Adaptive Stewardship Plan, available at www.cwsd.org/carson-river-watershed-adaptivestewardship-plan/ (accessed on 7 March 2017).

[16] Lewis, S.R. \& Cobourn, J., River Corridor Protection: Carson River Coalition's Main Message, University of Nevada Cooperative Extension, Fact Sheet 04-71, available at unce.unr.edu/publications/files/nr/2004/fs0471.pdf (accessed 7 March 2017).

[17] Nevada Division of Water Planning, The Flood of 1997, Final Report, available at water.nv.gov/home/pdfs/the\%20flood\%20of\%201997\%20final\%20report.pdf (accessed 7 March 2017).

[18] Mount, J.F., California Rivers and Streams: The Conflict Between Fluvial Process and Land Use, University of California Press: Berkeley, CA, pp. 292-312, 1995.

[19] U.S. Army Corps of Engineers, Sharing the Challenge: Floodplain Management into the 21st Century, available at www.floods.org/PDF/Sharing_the_Challenge.pdf, 1994 (accessed 7 March 2017).

[20] Carson Water Subconservancy District, Carson River Watershed Regional Floodplain Management Plan, available at cwsd.org/library/Final\%20floodplain\%20plan\% 209-08.pdf (accessed 7 March 2017).

[21] Douglas County, Nevada, Chapter 6: Growth management. Douglas County Master Plan of 2011, Vol. II, available at www.douglascountynv.gov/DocumentCenter/Home/ View/936 (accessed 7 March 2017).

[22] Cobourn, J. \& Lewis, S.R., Floodplain Protection Inventory for the Carson River, University of Nevada Cooperative Extension, Special Publication 15-05, available at unce. unr.edu/publications/files/nr/2015/fs1505.pdf (accessed 7 March 2017). 